\title{
Simulation of water quality for the El-Salam canal in Egypt
}

\author{
W. M. A. Khalifa \\ Department of Civil Engineering, Hail University, \\ Kingdom of Saudi Arabia and Fayoum University, Egypt
}

\begin{abstract}
A study is applied to simulate the water quality along El-Salam canal which was constructed to provide irrigation water in the northern Delta and northern Sinai Peninsula in Egypt. The canal receives both freshwater from Damietta branch and polluted drainage water from the Bahr Hadous, as well as drainage water delivered by the Lower Serw pumping station. The focus of this study is to simulate the oxygen (DO), chemical oxygen demand (COD), and ammonia $\left(\mathrm{NH}_{4}\right)$ based on reaeration rates, measured concentration of DO, COD, and $\mathrm{NH}_{4}$ and assumed growth and respiration parameters of algae and bacteria using the computerized program for aquatic simulation systems (AQUASIM). Due to lack of data for quantifying these processes, this last model application is speculative. Nevertheless, it is interesting because it shows a direction to which river water quality modeling would have to proceed in order to increase its predictive capabilities. The calibrated model is useful for the prediction of possible water quality along the canal when it comes into full operation.

Keywords: water quality models, El-Salam canal, dissolved oxygen, ammonia, nitrification, primary production, respiration, COD, eutrophication.
\end{abstract}

\section{Introduction}

El-Salam canal is a part of the North Sinai development project, which is one of the largest drainage water reuse projects in Egypt. The Egyptian Government envisage the reclamation of an estimated 260,400 hectares of desert situated along the Mediterranean coast of Sinai by diverting considerable amounts of agriculture drainage water from Hadous and Lower Serw drains, which receive almost all kinds of wastes to newly reclaimed areas after blending with Nile 
water in a ratio about 1:1 (Hafez [1], Abu-Salama [2], and Loutfy [3]). El-Salam canal originates from the Nile at km 219 on Damietta branch and runs towards the Suez Canal for about $89.4 \mathrm{~km}$ before it goes to the Sinai Peninsula through a siphon. About 1.9 and 0.4 milliard $\mathrm{m}^{3}$ will be discharged from Hadous and ElSerw drains into El-Salam canal, respectively, when the canal comes into full operation. Water quality has been monitored along El-Serw and Hadous drains since 1997 and along El-Salam canal since 1998 (El-Degwi et al. [4]). A study has been conducted by El-Degwi et al. [4] to investigate the BOD pollution rates from Non-Point Sources (NPS) along various zones of El-Salam canal as well as estimating the BOD variation along the canal using the water quality data measured in the period of 1997-2001 by the Drainage Research Institute (DRI) of Egypt and a numerical model QUAL2E. They also conducted a statistical analysis to compute the maximum, the average, the minimum and the upper/ lower limits of BOD either measured at monitoring stations of El-Serw and Hadous drains or estimated along various zones (NPS). Results from the statistical analysis of water quality either measured or estimated were of good help for the prediction of possible water quality along the canal when it comes into full operation. The goal of the present study is to simulate the water quality parameters, $\mathrm{DO}, \mathrm{COD}, \mathrm{NH}_{4}$ using the water quality data during the period 2005 and AQUASIM model. The governing equations and the numerical model used are described before El-Salam canal data are introduced. Calibration results of the technique adopted are presented and discussed and, finally, conclusions and recommendations are given.

\section{Study site}

The canal El-Salam starts at its intake on the right bank of Damietta Branch of the Nile, some $3 \mathrm{~km}$ upstream of the Farskour Dam. The total length of the canal is $252.750 \mathrm{~km}$ and comprises two main parts. One part, $89.750 \mathrm{~km}$ long, lies to the west of the Suez Canal and is named El-Salam Canal. The other part, $163.000 \mathrm{~km}$ long, is located to the east of the Suez Canal and is named El-Sheikh Gaber Canal. Both parts are connected through El-Salam Siphon, a $770 \mathrm{~m}$ long inverted siphon under the Suez Canal as shown in Figure 1.

The total length of El-Salam canal $(89.750 \mathrm{~km})$ is divided into three reaches with a medium gradient of $6 \mathrm{~cm} / \mathrm{km}$. The first reach starts from the intake on Damietta branch, about $3 \mathrm{~km}$ upstream of the Farskour Dam, at a water level of $(+1.70) \mathrm{m}$ MSL and extends to El-Salam 1 pumping station $(23.050 \mathrm{~km}$ DS the intake) which is lifting water from level $(+0.50)$ to $(+2.25) \mathrm{m}$ MSL. The first reach of El-Salam canal is mixed with Lower El-Serw Drain $(18.390 \mathrm{~km}$ DS the intake). The second reach extends from El-Salam 1 pumping station crossing Hadous Drain (53.950 km DS of the intake) in a siphon passing under the drain to El-Salam 2 pumping station $(54.300 \mathrm{~km}$ DS of the intake) which is lifting water from level $(+0.50)$ to $(+3.00) \mathrm{m}$ MSL. The last reach extends from ElSalam 2 pumping station to the Siphon under the Suez Canal $(89.750 \mathrm{~km}$ DS the intake). 


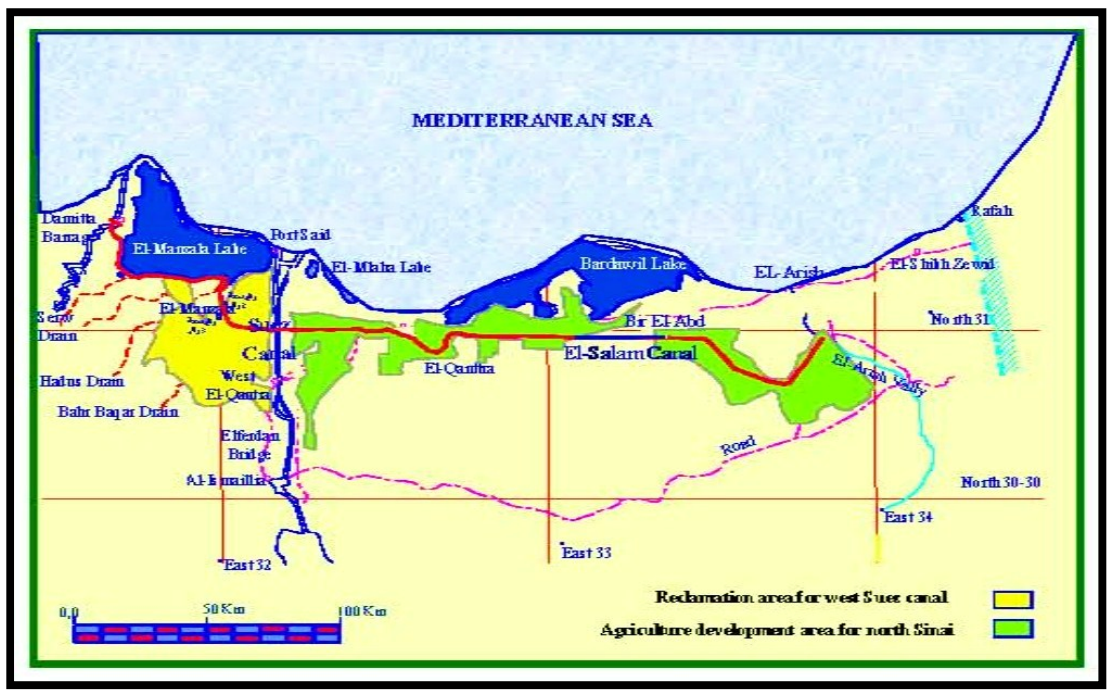

Figure 1: $\quad$ Map of El-Salam canal.

Through the third reach, El-Salam 3 pumping station $(54.870 \mathrm{~km}$ DS the intake) is lifting water from Hadous Drain to mix it in the El-Salam canal at level $(+3.00) \mathrm{m}$ MSL. Figure 2 shows an overall schematic diagram for El-Salam canal.

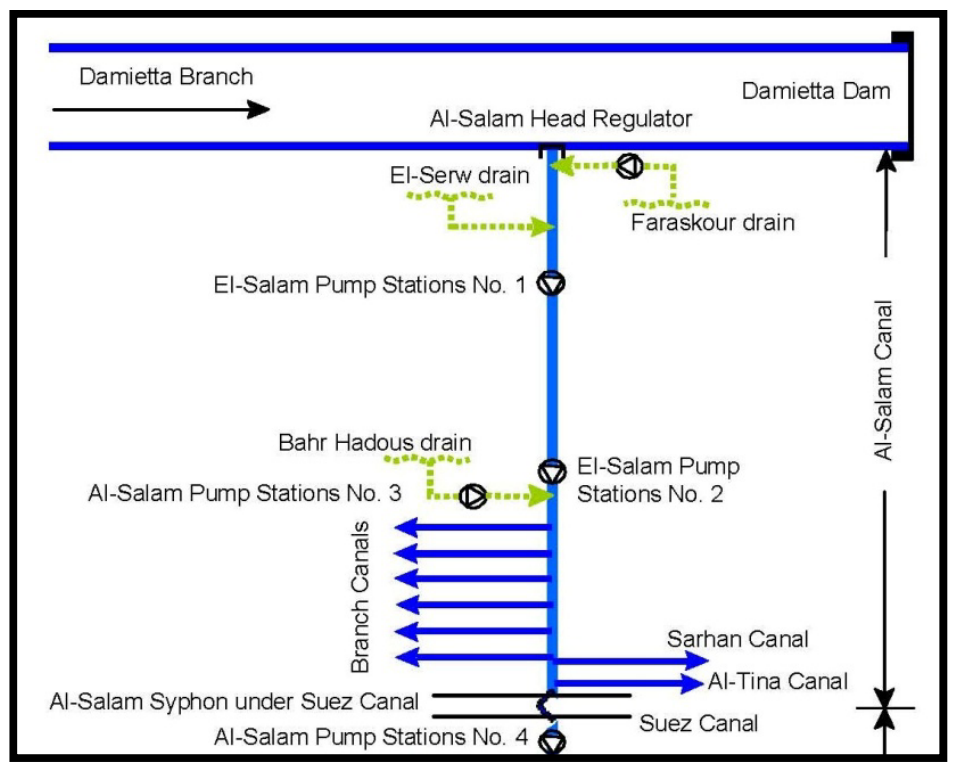

Figure 2: $\quad$ Schematic diagram of El-Salam canal. 
In this study, four trapezoidal cross-sections were selected at the terms of three reaches with surface width ranges from $44.36 \mathrm{~m}$ at the intake to $57.92 \mathrm{~m}$ at the Siphon under Suez Canal. Furthermore, the El-Salam canal is affected by the mixing of wastewater at El-Serw Drain and Hadous Drain at the first and third reach as located above, respectively.

The temporal and spatial dynamics of flow and physico-chemical parameters were measured during 2005 by Drainage Research Institute (DRI), Water Research Center, Egypt. The surface water body was continuously measured (every nearly one month) in monitoring stations at El-Salam intake, El-Serw Feeder, El-Salam station 3 (Hadous Drain), and US Siphon under Suez Canal, respectively for $\mathrm{pH}, \mathrm{TDS}, \mathrm{DO}, \mathrm{COD}, \mathrm{BOD}, \mathrm{NH}_{4}$. The temperature was measured in 2005 every day. The intensity of light was estimated by Burgess [5].

\section{Modelling approach}

The study reach was modeled using measured cross-sectional profiles within the sampling reach, a constant slope, and an effective friction coefficient upstream of the sampling reach. River hydraulics was calculated with diffusive wave approximation to the full one-dimensional river hydraulics equations according to de St. Venant. The two most important approximations to these equations are implemented in AQUASIM (Reichert [6]) to describe river hydraulics.

The equations for river hydraulics are coupled with advection-diffusion equations to describe transport of substances dissolved or suspended in the water. Accordingly, these lead to the following set of two differential equations. The first equation describes water flow through the compartment:

$$
\frac{\partial A}{\partial t}+\frac{\partial Q}{\partial x}=q
$$

The temporal change in wetted cross-sectional area, $A$, is determined by the spatial gradient of the discharge, $Q$, and by the lateral inflow, $q$. The second equation describes the behavior of substances transported with the water flow:

$$
\frac{\partial A C}{\partial t}=-\frac{\partial}{\partial x}(Q C)+\frac{\partial}{\partial x}\left(A E \frac{\partial C}{\partial x}\right)+r+S_{q n}
$$

The concentration is affected by advection with the water flow (first term), longitudinal dispersion (second term), transformation processes (third term), and by lateral inflow or outflow (fourth term).

In order to make the solution to the above system of differential equations unique, one boundary condition is necessary for Equation (1) and two boundary conditions are required for the partial differential Equation (2). The boundary condition for the Equation (1) that describes discharge through the river sections, at the start point, $x_{s}$ is given by: 


$$
Q\left(x_{s}\right)=Q_{\text {in }}
$$

The boundary conditions for Equation (2) are given by the continuity of the substance mass flows entering the river section and by a transmission boundary condition at the end of the compartment:

$$
\begin{gathered}
Q\left(x_{s}\right) C-A E \frac{\partial C}{\partial x}=I_{i n, C} \\
\frac{\partial^{2} C}{\partial x^{2}}=0
\end{gathered}
$$

where $I_{i n, C}$ is the total mass input of substance described by the concentration $C$ per unit time. The second of these boundary conditions, Equation (5), is omitted for dispersion-free transport. In the second term of Equation (2), the longitudinal dispersion coefficient is estimated according to Fischer et al. [7] as:

$$
E=c_{f} \frac{w^{2} v^{2}}{u^{*} d}
$$

where $c_{f}$ is a non-dimensional dispersion coefficient, $w$ is the surface width of the river, $d$ is the mean river depth, and $u^{*}=\sqrt{g d S_{f}}$ is the friction velocity. The empirical expression;

$$
S_{f}=\frac{1}{K_{s t}^{2}} \frac{1}{R^{4 / 3}} v^{2}
$$

Accordingly, Manning-Strickler is used to calculate the friction slope. In this equation $K_{s t}$ is the friction coefficient according to Strickler, $R$ is the hydraulic radius of the river, and $v$ is the cross-sectionally averaged flow velocity.

The study of El-Salam canal was modeled using measured cross-section profiles throughout the length of the canal, a constant slope, and an effective coefficient through every reach of the canal. All simulations were performed with the simulation and data analysis tool AQUASIM (Reichert [6]). More information on this program is available at http://www.aquasim.eawag.ch.

The calibration of the effective Strickler friction coefficient in the three reaches of El-Salam canal $\left(K_{s t, a}, K_{s t, b}, K_{s t, c}\right)$ could be done according to their bed type and slope. The non-dimensional dispersion coefficient $c_{f}$ was taken a constant value based on the tracer transients in the water column (Borchardt and Reichert [8]). The values of the estimated parameters are given in Table 1.

\section{Modelling for oxygen, carbon, and nitrogen}

The oxygen balance of El-Salam canal is characterized by high daily and seasonal temporal dynamics triggered from radiation and intense production- 
Table 1: Hydraulics parameter estimates for El-Salam canal.

\begin{tabular}{ccc}
\hline Parameter & Unit & Value \\
\hline$K_{s t, a}$ & $\mathrm{~m}^{1 / 3} \mathrm{~s}^{-1}$ & 45.0 \\
$K_{s t, b}$ & $\mathrm{~m}^{1 / 3} \mathrm{~s}^{-1}$ & 42.5 \\
$K_{s t, c}$ & $\mathrm{~m}^{1 / 3} \mathrm{~s}^{-1}$ & 40.0 \\
$c_{f}$ & & 0.0065 \\
\hline
\end{tabular}

respiration-nitrification processes. This leads to more speculative results but it is a good first step towards a model with better predictive capabilities that tries to simulate the dynamics of algae and bacteria. According to Equation (2), it can be modeled the oxygen balance with a simple version of AQUASIM using the following equation:

$$
\begin{gathered}
r=K_{2}\left(C_{s a t}-C_{O 2}\right)+\frac{P I}{d}-\frac{R}{d}-K_{d e g} \frac{C_{O 2}}{K_{O 2}+C_{O 2}} C_{C O D} \\
-K_{n i t} \frac{C_{O 2}}{K_{N I T}+C_{O 2}} C_{N H 4}
\end{gathered}
$$

where $r$ is the net oxygen production rate, $K_{2}$ is the reaeration rate constant, $C_{\text {sat }}$ is the oxygen saturation concentration, $C_{O 2}$ is the oxygen concentration, $I$ is the light intensity, $d$ is the mean river depth, $P$ and $R$ are production and respiration parameters of algae and bacteria, $K_{d e g}$ is the degradation rate constant, $K_{O 2}$ is the half saturation concentration with respect to oxygen, $C_{C O D}$ is the concentration of $\mathrm{COD}, K_{n i t}$ is the nitrification rate constant, $K_{N I T}$ is the half saturation concentration with respect to nitrification, ad $C_{N H 4}$ is the concentration of $\mathrm{NH}_{4}$.

Estimates for physical reaeration based on empirical assessments were included in Khalifa [9] with consideration of given flow velocities and water depth for the investigation periods. Empirical formulas resulted in $K_{2}$-values ranging from 17.0-29.0 $\mathrm{d}^{-1}$ (Borchardt and Reichert [8]). For model calculations, it has been selected a value for $K_{2}=20 \mathrm{~d}^{-1}$. The fit results shown in Table 2 are conditional on this value. The oxygen saturation concentration formula was given in APHA [10]. Thomann and Mueller [11] reported an approximate value of $K_{\text {deg }}$ ranged from 0.5 to $3.0 \mathrm{~d}^{-1}$ and $K_{\text {nit }}$ ranged from 0.1 to $1.25 \mathrm{~d}^{-1}$. The effect of the effluents on oxygen concentration in the canal is based on a degradation rate coefficient $\left(K_{\text {deg }}\right)$ and a nitrification rate $\left(K_{\text {nit }}\right)$ of $1.0 \mathrm{~d}^{-1}$ for both. The values of $K_{O 2}$ and $K_{N I T}$ are taken, in the model, with $0.5\left(\mathrm{~g} \mathrm{O}_{2} / \mathrm{m}^{3}\right)$ and $2.0\left(\mathrm{~g} \mathrm{O}_{2} / \mathrm{m}^{3}\right)$, respectively as presented in Khalifa [9]. In the ammonia modeling,

Table 2: Parameter estimates from oxygen time series.

\begin{tabular}{ccc}
\hline Parameter & Unit & Value \\
\hline $\mathrm{P}$ & $\mathrm{g} /(\mathrm{Wd})$ & 0.05 \\
$\mathrm{R}$ & $\mathrm{g} /\left(\mathrm{m}^{2} \mathrm{~d}\right)$ & 20 \\
\hline
\end{tabular}


the term of nitrification shown in Equation (8), can be reduced by $80 \%$ as in Khalifa [9].

Based on these boundary conditions, production-respiration-nitrification rate parameters were estimated from continuously measured oxygen, chemical oxygen demand, and ammonia time series (Ministry of Water Resources and Irrigation \& Resources Technology Bureau Resources Technology Bureau (RTB) [12]). With this approach, Figure 3, Figure 4, and Figure 5 show
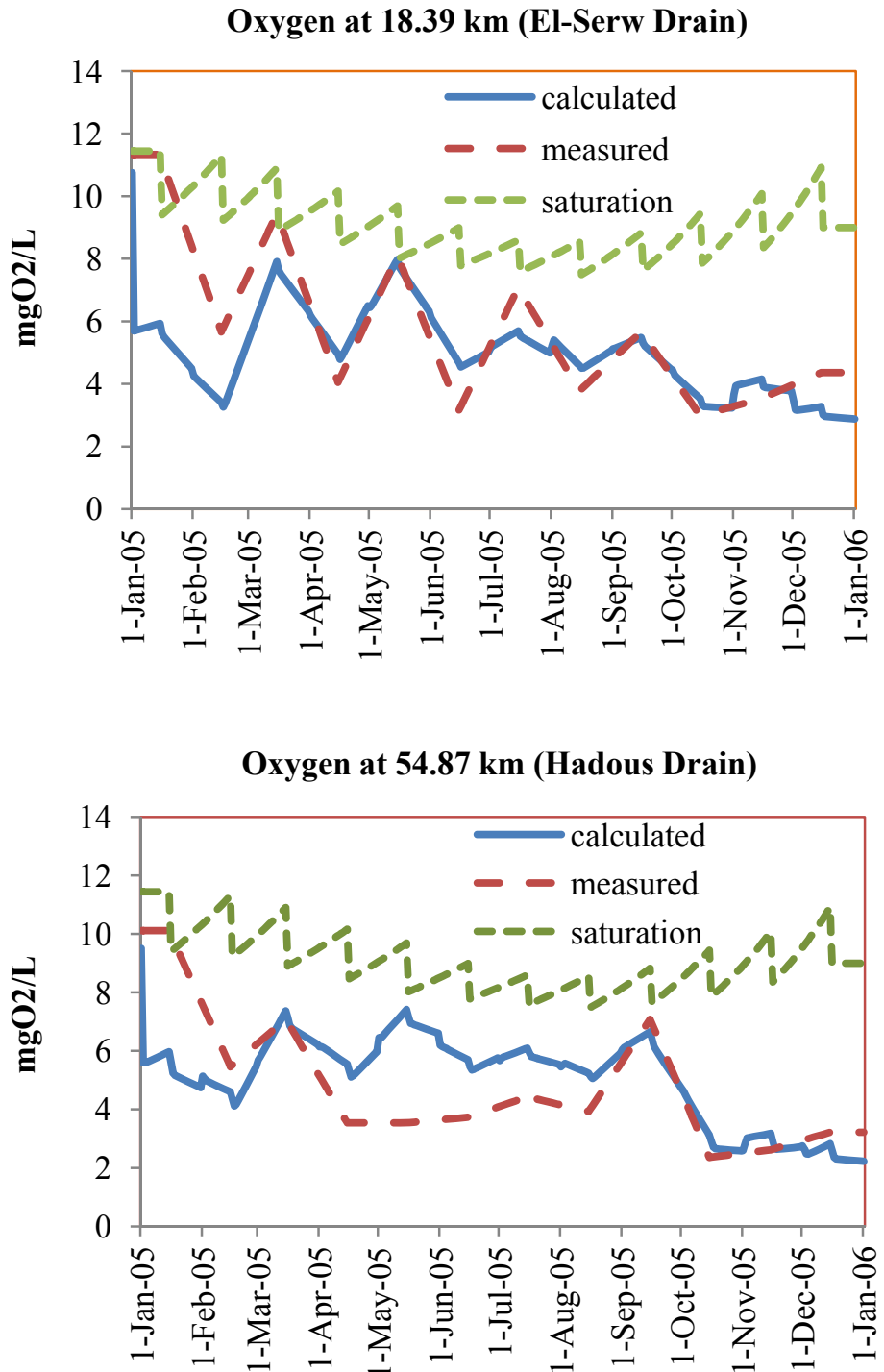

Figure 3: Oxygen time series for El-Salam canal. 

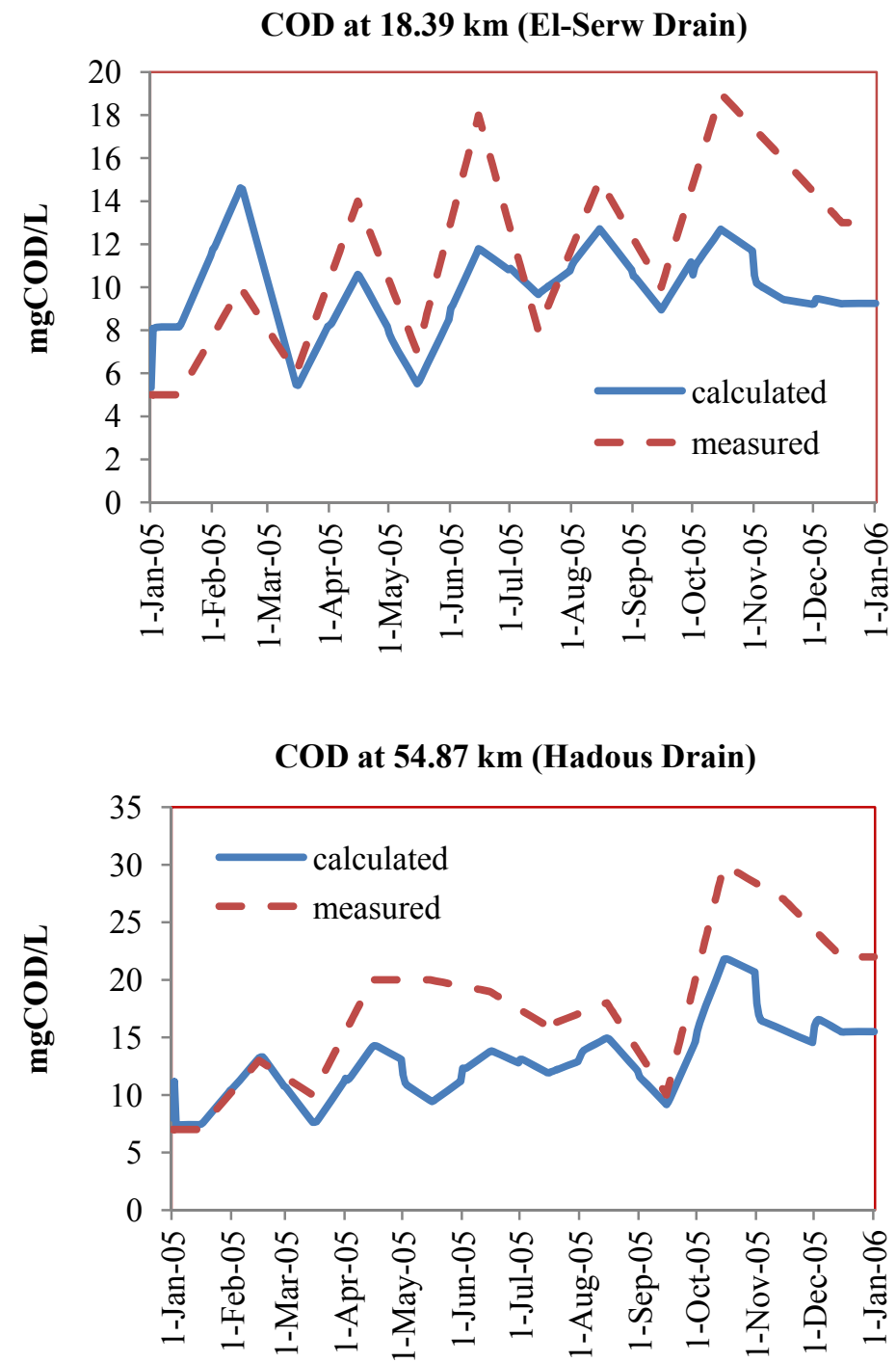

Figure 4: Chemical oxygen demand time series for El-Salam canal.

measured and calculated concentrations of oxygen, chemical oxygen demand, and ammonia at El-Serw and Hadous Drains of El-Salam canal, respectively. As the approach stated, the good agreement of calculated with measured concentrations indicates that there is no significant change of active biomass in El-Salam canal during the measurements periods. 

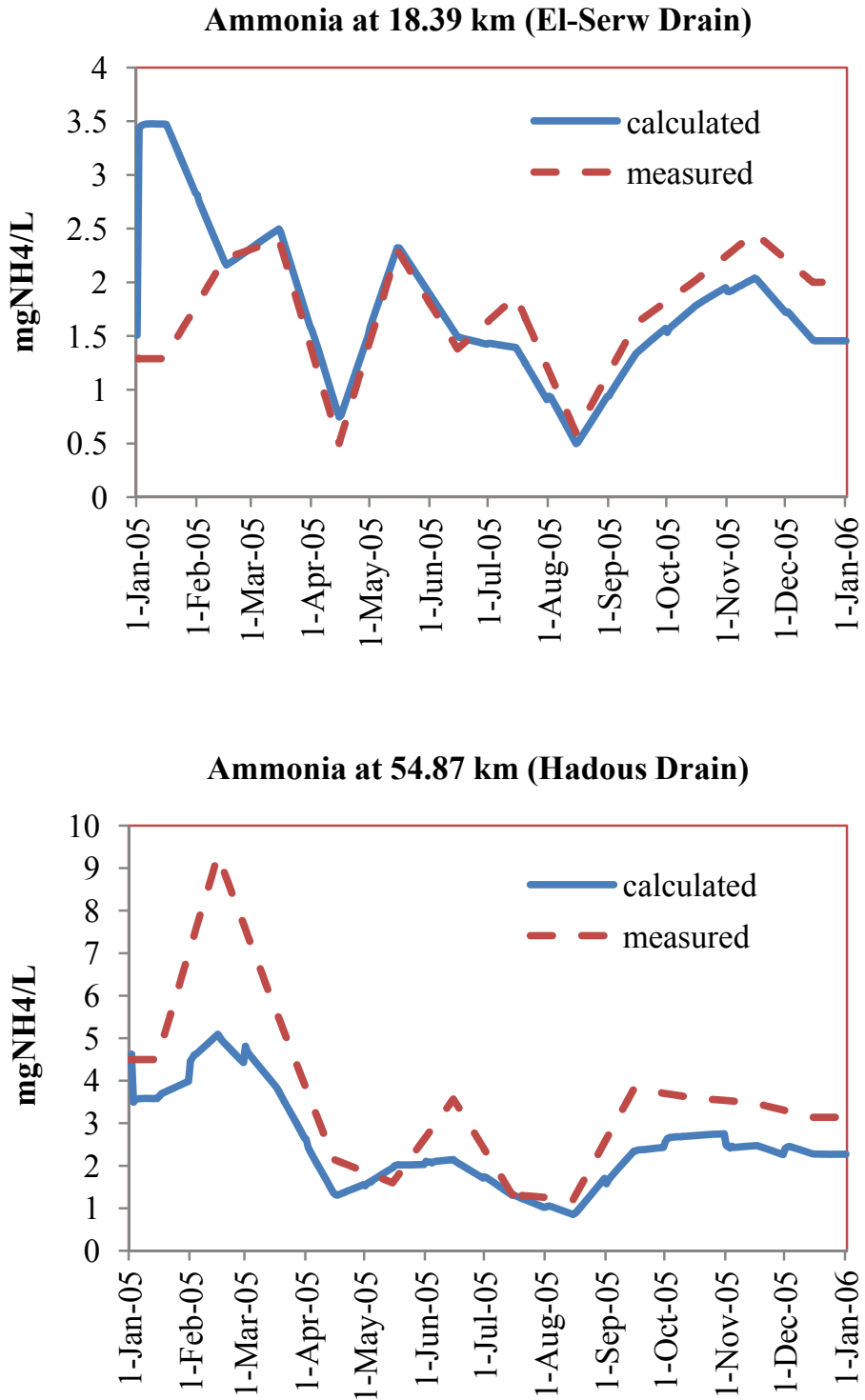

Figure 5: Ammonia time series for El-Salam canal.

\section{Conclusions}

This study has been conducted to simulate the oxygen, chemical oxygen demand, and ammonia through El-Salam canal in Egypt using AQUASIM model. This 
could be achieved with a systematic procedure of canal compartmentalization including identification of flows and strongly simplified description of biochemical conversion processes.

The modeling approach makes it possible to quantify the temporal dynamic of oxygen, chemical oxygen demand, and ammonia in surface flow for spatially averaged scales, but with consideration of distinct patterns at the terms of ElSalam canal using physico-chemical data in 2005. This opens new perspectives to study ecological relevant system responses to algal species and anthropogenic impact.

Further research directions should be directed into these subjects in El-Salam canal in order to achieve an ecologically meaningful canal water quality modeling. In those efforts the AQUASIM modeling approach may be applied to questions of system analysis at different levels of complexity and for different types of human impact. The approach would support the functional understanding of ecological processes in canals and the identification of ecological effective management strategies.

\section{References}

[1] Hafez, A., Investigation of El-Salam Canal Project in Northern Sinai, Egypt, Ninth International Water Technology Conference, IWTC9, Sharm El-Sheikh, Egypt, pp. 953-970, 2005.

[2] Abu-Salama, M.S.M., Spatial and Temporal Consolidation of Drainage Water Quality Monitoring Networks: A Case Study From the El-Salam Canal Project in Egypt, Ph.D. Thesis, Faculty of Environment and Technology, Leuphana University Lüneburg, Germany, 2007.

[3] Loutfy, N.M., Reuse of Wastewater in Mediterranean Region (Egyptian Experience), Waste Water Treatment and Reuse in the Mediterranean Region, Springer-Verlag Berlin Heidelberg, 2010.

[4] El-Degwi, A.M.M., Ewida, F.M. \& Gawad, S.M., Estimating BOD Pollution Rates along El-Salam Canal Using Monitored Water Quality Data (1998-2001), 9th International Drainage Workshop, Utrecht, the Netherlands, September 10-13, 2003.

[5] Burgess, P., Variation in Light Intensity at Different Latitudes and Seasons, Effects of Cloud Cover, and the Amounts of Direct and Diffused Light, Presentation to Continuous Cover Forestry Group (CCFG) Scientific Meeting, Westonbirt Arboretum, Gloucestershire, 29 September 2009.

[6] Reichert, P., Computer Program for the Identification and Simulation of Aquatic Systems, Swiss Federal Institute for environmental Science and Technology (EAWAG), CH-8600 Dübendorf, Switzerland, ISBN: 3906484-16-5, 1998.

[7] Fischer, H.B., Liet, E., Koh, C., Imberger, J. \& Brooks, N., Mixing in Inland and Coastal Waters, Academic Press, New York, 1979. 
[8] Borchardt, D. \& Reichert, P., River Water Quality Model No. 1: Compartmentalisation Approach Applied to Oxygen Balances in the River Lahn (Germany), Water Science and Technology, Vol. 43, No. 5, pp 1-9, 2001.

[9] Khalifa, W.M.A., Two Dimensional Finite Difference Model for Water Quality in Lakes, Ph.D. Thesis, Faculty of Engineering, Cairo University, Egypt, 2000.

[10] APHA (American Public Health Association), Standard Methods for the Examination of Water and Waste Water, $16^{\text {th }}$ edition, Washington, D.C, 1985.

[11] Thomann, R.V. \& Mueller, J.A., Principles of Surface Water Quality Modeling and Control, Harper \& Row Publishers, Inc., New York, ISBN: 0-06-046677-4, 1989.

[12] Ministry of Water Resources and Irrigation \& Resources Technology Bureau (RTB), Action 6; The Execution of Specific Assessments in the Coastal Areas of Port Said: Water Resources (Final Report), 2007. 